Andrzej Szmyt

Uniwersytet Gdański, Gdańsk

\title{
Uregulowania konstytucji krajowej w perspektywie integracji europejskiej oraz kierunki niezbędnych uzupełnień
}

DOI: http://dx.doi.org/10.12775/SIT.2014.017

\section{Uwagi wprowadzające}

Konstytucja Rzeczypospolitej Polskiej z dnia 2 kwietnia 1997 roku $^{1}$ zawiera od początku jej obowiązywania dwa przepisy istotne dla materii „unijnej” (integracyjnej), mianowicie art. 90 i art. 91 ust. 3.

Przepisy art. 90 konstytucji stanowią, że Rzeczpospolita Polska może na podstawie umowy międzynarodowej przekazać organizacji międzynarodowej lub organowi międzynarodowemu kompetencje organów władzy państwowej w niektórych sprawach (ust. 1), przy czym ustawa wyrażająca zgodę na ratyfikację umowy międzynarodowej, o której mowa w ust. 1, jest uchwalona przez Sejm większością $2 / 3$ głosów w obecności co najmniej połowy ustawowej liczby posłów oraz przez Senat większością $2 / 3$ głosów w obecności co najmniej połowy ustawowej liczby senatorów (ust. 2). W przywołanym artykule mowa tez o tym, że wyrażenie zgody na ratyfikację takiej umowy może być uchwalone w referendum ogólnokrajowym zgodniez przepisem art. 125 ust. 3; samą uchwałę w sprawie wyboru trybu wyrażenia zgody na ratyfikację podejmuje Sejm bezwzględną

${ }^{1}$ Dz.U. Nr 78, poz. 483, ze zm. 
większością głosów w obecności co najmniej połowy ustawowej liczby posłów (ust. 4).

Przepis art. 91 ust. 3 konstytucji stanowi, że jeżeli wynika to $z$ ratyfikowanej przez Rzeczpospolitą Polską umowy konstytuującej organizację międzynarodową, prawo przez nią stanowione jest stosowane bezpośrednio, mając pierwszeństwo w przypadku kolizji z ustawami.

Mówiąc krótko, art. 90 konstytucji stanowi podstawę dla ograniczonego przekazania kompetencji organów władzy państwowej (w tym zręby proceduralne), zaś art. 91 ust. 3 określa miejsce prawa stanowionego przez organizacje międzynarodowe w krajowym systemie prawnym. Jak widać, przepisy te nie odnoszą się wprost do jednej, określonej $z$ nazwy organizacji międzynarodowej ${ }^{2}$, ale sformułowane są w sposób uniwersalny, choć tworzone były z myślą o umożliwieniu przystąpienia Polski do Unii Europejskiej - co też się stało w 2004 roku. Zakres regulacji konstytucyjnej jest tak wąski, bo tłumaczy się genezą konstytucji - ustrojodawca uznał wówczas za możliwe ograniczenie się do minimum regulacyjnego, które umożliwiłoby akt akcesyjny. Zabrakło wówczas ustanowienia regulacji wielu ważnych zagadnień z zakresu „materii unijnej”, zwłaszcza - w wymiarze prakseologicznym - dotyczących działania organów państwa w strukturach unijnych ${ }^{3}$, co w praktyce ustrojowej zaowocowało politycznoprawnymi konfliktami, zwłaszcza w łonie egzekutywy ${ }^{4}$.

${ }^{2}$ Zwraca na to uwagę J. Galster, Konstytucja Rzeczypospolitej Polskiej wobec postępów integracji europejskiej. Diagnoza stanu europeizacji ustawy zasadniczej, w: Dziesięć lat Konstytucji Rzeczypospolitej Polskiej, red. E. Gdulewicz, H. Zięba-Załucka, Rzeszów 2007, s. 56.

${ }^{3}$ Zob. A. Szmyt, O dwóch przykładach watpliwości $w$ sprawie zamierzeń legislacyjnych, w: Państwo i prawo wobec współczesnych wyzwań, t. 3: Zagadnienia prawa konstytucyjnego. Księga jubileuszowa Profesora Jerzego Jaskierni, red. R. M. Czarny, K. Spryszak, Toruń 2012, s. 176.

${ }^{4}$ Zob. zwłaszcza postanowienie Trybunału Konstytucyjnego z 29 maja 2009 roku (sygn. Kpt 2/08) o treści i granicach kompetencji Prezesa Rady Ministrów oraz Prezydenta RP w zakresie reprezentowania Rzeczypospolitej Polskiej na posiedzeniach Rady Europejskiej. 
Problem „wymiaru unijnego” Konstytucji RP szybko stał się przedmiotem szerokich analiz doktrynalnych, prowadząc rychło do daleko idącego konsensusu co do potrzeby, granic i meritum pożądanych uzupełnień oraz zmian w treści obowiązującej ustawy zasadniczej, w tym również wskazania, że - w zasadzie - materia ta winna stanowić przedmiot uregulowania kompleksowego w jednym, nowym rozdziale konstytucji ${ }^{5}$. Swoistym „ukoronowaniem” tego nurtu jest zapewne projekt ustawy o zmianie konstytucji (wraz z uzasadnieniem) z 30 czerwca 2010 roku, stanowiący bezpośrednio rezultat prac zespołu naukowego, powołanego przez Marszałka Sejmu ${ }^{6}$.

Natomiast trudno byłoby mówić o widocznym zaangażowaniu $\mathrm{w}$ tej materii podmiotów wyposażonych konstytucyjnie $\mathrm{w}$ prawo inicjatywy w zakresie nowelizacji konstytucji. Zgodnie $z$ art. 235 konstytucji, projekt ustawy o zmianie konstytucji może przedłożyć co najmniej $1 / 5$ ustawowej liczby posłów (tj. 92 posłów), Senat lub Prezydent RP. W czasie 14 lat obowiązywania Konstytucji RP (1997-2011), czyli do końca VI kadencji Sejmu, przedłożono oficjalnie Sejmowi 16 projektów ustaw o zmianie konstytucji, z czego dwie zmiany zostały uchwalone ${ }^{7}$.

Wśród owych 16 projektów cztery istotne zostały wniesione do Sejmu w drugiej połowie VI kadencji. Trzy z nich dotyczyły - po raz pierwszy w 12 roku obowiązywania konstytucji - „materii unijnej”. Żaden $z$ tych projektów nie został jednak uchwalony i z końcem kadencji Sejmu zostały one objęte zasadą dyskontynuacji. Stanowią one jednak oficjalny obraz wyobrażeń i dążeń sił politycznych co do konstytucyjnej regulacji interesującej nas materii. Zapewne

${ }^{5}$ Por. A. Kustra, „Euronowelizacja” w projektach o zmianie ustaw Konstytucji RP. Próba oceny, ,Przegląd Sejmowy” 2011, nr 3, s. 35-37.

${ }^{6}$ Zob. Zmiany $w$ Konstytucji RP dotyczace członkostwa Polski $w$ Unii Europejskiej. Dokumenty z prac zespołu naukowego powołanego przez Marszałka Sejmu, Warszawa 2010.

7 Uchwalono zmianę art. 558 września 2006 roku w zakresie modyfikacji zasad ekstradycji obywatela (Dz.U. Nr 200, poz. 1471) oraz zmianę art. 99 7 maja 2009 roku w zakresie ograniczenia biernego prawa wyborczego osób skazanych (Dz.U. Nr 114, poz. 946). 
też stanowić będą istotny czynnik regulacji tych spraw w przyszłości i w tym sensie nadal mają znaczenie jako przedmiot naszej uwagi.

Wspomniane cztery projekty ustaw o zmianie konstytucji to:

1. Projekt poselski grupy posłów $z$ opozycyjnej partii Prawo i Sprawiedliwość z 6 listopada 2009 roku $^{8}$ dotyczący art. 188 konstytucji (rozszerzający kognicję Trybunału Konstytucyjnego na tzw. wtórne prawo unijne) i art. 190 konstytucji (kwestia ogłaszania orzeczeń Trybunału Konstytucyjnego, będących realizacją nowej kompetencji $z$ art. 188).

2. Projekt poselski grupy posłów rządzącej partii Platforma Obywatelska $z 19$ lutego 2010 roku $^{9}$ dotyczący - po raz pierwszy w praktyce ustrojowej - dużej liczby przepisów konstytucji, głównie $z$ zakresu organów państwa. Projekt ten nie miał wprawdzie odniesień do problematyki unijnej, ale wspominamy o nim z przyczyn proceduralno-organizacyjnych, o czym niżej.

3. Projekt prezydencki $z 12$ listopada 2010 roku $^{10}$ dotyczący kompleksowo kwestii wynikających z przynależności Polski do Unii Europejskiej.

4. Projekt poselski grupy posłów partii opozycyjnej Prawo i Sprawiedliwość z 26 listopada 2010 roku $^{11}$ dotyczący kompleksowo interesujących nas kwestii integracyjnych.

Oba projekty wniesione przez posłów opozycji oraz projekt prezydencki tworzyły „blok unijny” proponowanych nowelizacji konstytucji. Najistotniejsze znaczenie odgrywał w nim projekt prezydencki i jemu też poświęcamy poniższe uwagi.

${ }^{8}$ Druk sejmowy nr 3399.

9 Druk sejmowy nr 2989. Szerzej o tym projekcie A. Szmyt, Aktualne problemy rozwoju prawa konstytucyjnego $w$ Polsce ( $w$ świetle projektu ustawy o zmianie Konstytucji z 19 lutego 2010 r.),w: Ustavni system Ceske Republiky a Polske Republiky po pristoupeni $k$ Europske Unii, red. V. Jiraskova, Z. Witkowski, Praga 2011, s. 19-36.

${ }^{10}$ Druk sejmowy nr 3598.

11 Druk sejmowy nr 3687. 


\section{Projekt ustawy o zmianie Konstytucji RP $z$ dnia 12 listopada 2010 r. (druk sejmowy nr 3598) wniesiony do Sejmu przez Prezydenta RP}

Na wstępie godzi się zaznaczyć, że prezydencki projekt nowelizacji konstytucji w bardzo dużym stopniu - choć nie całkowicie ${ }^{12}$ - bazuje na sygnalizowanym wcześniej projekcie, stanowiącym rezultat prac (ostateczna wersja pochodzi z 30 czerwca 2010 roku) zespołu powołanego przez Bronisława Komorowskiego jeszcze jako Marszałka Sejmu. W projekcie prezydenckim zwraca uwage - przede wszystkim - propozycja (art. 1 pkt 8) wprowadzenia do konstytucji nowego rozdziału Xa, zatytułowanego „Członkostwo Rzeczypospolitej Polskiej w Unii Europejskiej”, stanowiącego kompleksową regulację (art. 227a-227k). Nie jest to więc formuła uniwersalna, dotycząca także innych organizacji międzynarodowych. Ponadto projekt zawiera kilka propozycji zmian związanych $z$ uczestnictwem Polski w Unii Gospodarczej i Walutowej, umożliwiającej (w przyszłości) wprowadzenie waluty euro (art. 1 pkt. 2-7, w sensie techniczno-legislacyjnym poprzedzających przepisy nowego rozdz. Xa konstytucji ${ }^{13}$. Uwagi do brzmienia proponowanych przepisów w istotnej mierze bazują na stanowisku wnioskodawcy, zaprezentowanym w uzasadnieniu projektu.

W zakresie nawiązującym do regulacji związanych z wprowadzeniem waluty euro, w uzasadnieniu projektu podkreśla się koniecz-

12 Inaczej niż w projekcie naukowym, projekt prezydencki nie zawiera przepisu o wydawaniu przez Radę Ministrów rozporządzeń z mocą ustawy w celu wykonania prawa Unii Europejskiej, zawiera zaś dodatkowo przepis dotyczący wprost roli Prezydenta RP, ponadto zaś w art. 227g ma zmieniony kształt rozwiązania - tu bowiem obecne brzmienie stanowiło w projekcie naukowym treść ust. 2, zaś ust. 1 przewidywał, że prawo UE stanowi część krajowego porządku prawnego i jest stosowane zgodnie $z$ zasadami wynikającymi $z$ traktatów stanowiących podstawę UE.

${ }^{13} \mathrm{O}$ projekcie prezydenckim interesujące uwagi przedstawia A. Kustra, op.cit., passim. 
ność usunięcia $z$ polskiego systemu prawnego przepisów mogących osłabiać skuteczność prawa unijnego w dziedzinie polityki pieniężnej oraz podważać niezależność Narodowego Banku Polskiego. Trzon projektowanej zmiany stanowi nowe brzmienie art. 227 konstytucji, a uzupełniajają incydentalne zmiany w kilku innych przepisach ustawy zasadniczej.

Zgodnie $\mathrm{z}$ nowym brzmieniem art. 227 ust. 1 centralnym bankiem państwa jest Narodowy Bank Polski, który należy do Europejskiego Systemu Banków Centralnych. Narodowy Bank Polski zapewnia stabilność cen oraz realizuje zadania i wykonuje kompetencje określone w traktatach stanowiących podstawę Unii Europejskiej oraz w ustawie. Narodowy Bank Polski jest w swojej działalności niezależny od innych organów państwowych. Przepis wyraża nową filozofię statusu NBP - zwłaszcza przynależność do Europejskiego Systemu Banków Centralnych i wyraźne związanie traktatami. Nowością jest podkreślenie wprost niezależności od innych organów państwowych, z czym pozostaje w związku wykreślenie w art. 198 ust. 1 konstytucji Prezesa NBP jako ponoszącego odpowiedzialność konstytucyjną przed Trybunałem Stanu. W związku z koniecznością konwergencji z prawem unijnym, w przepisie nie mogły się znaleźć dotychczasowe przepisy, że NBP dysponuje wyłącznym prawem emisji pieniądza, ustalania i realizowania polityki pieniężnej oraz odpowiada za wartość polskiego pieniądza.

Zgodnie $z$ brzmieniem art. 227 ust. 2 Najwyższa Izba Kontroli kontroluje działalność Narodowego Banku Polskiego z punktu widzenia legalności, gospodarności, celowości i rzetelności w zakresie, w jakim nie dotyczy to realizowania zadań i wykonywania kompetencji określonych w traktatach stanowiących podstawę Unii Europejskiej. Nowością normatywną jest tu ograniczenie zakresu kontroli NIK (wskazane wykluczenie sfery traktatowej), a techniczno-legislacyjną konsekwencją - wykreślenie NBP z art. 203 ust. 1 konstytucji regulującego zakres kontroli NIK oraz wykreślenie w art. 204 ust. 1 pkt 1 fragmentu przepisu o przedkładaniu przez NIK Sejmowi analizy wykonania założeń polityki pieniężnej. W sensie formalnym ust. 2 jest w art. 227 nową jednostką.

Zgodnie $z$ nowym brzmieniem art. 227 ust. 3 organami Narodowego Banku Polskiego są Prezes Narodowego Banku Polskiego 
oraz Zarząd Narodowego Banku Polskiego. Oznacza to wykreślenie dotychczasowego organu NBP, jakim była też Rada Polityki Pieniężnej (dotychczasowy art. 227 ust. 2). Według projektu nastąpić ma całkowita dekonstytucjonalizacja Rady Polityki Pieniężnej, więc w art. 103 ust. 1 skreśla się też „członka Rady Polityki Pieniężnej” jako funkcję, z którą nie można łączyć mandatu posła, zaś w art. 144 ust. 3 skreśla się pkt 25, czyli wyłączenie spod kontrasygnaty prezydenckiego aktu powoływania (części) członków RPP.

W związku $z$ nowym statusem NBP (art. 227 ust. 1) i jego organami (ust. 3) w art. 227 (nowym brzemieniu) nie mogły się znaleźć dotychczasowe ust. 5 i 6, określające skład Rady Polityki Pieniężnej i jej kompetencje, dotyczące ustalenia założeń polityki pieniężnej i przedkładania ich do wiadomości Sejmowi oraz składania Sejmowi sprawozdań $z$ wykonania tych założeń.

W nowym brzmieniu art. 227 bez zmian - jedynie $z$ inną numeracją - miałyby pozostać dawne ust. 3 i 4, dotyczące powoływania Prezesa NBP, zakazu jego przynależności do partii politycznej, związku zawodowego oraz prowadzenia działalności niedającej się pogodzić $z$ godnością jego urzędu, a także dawny ust. 7, odsyłający do regulacji ustawowej wskazanych w nim spraw.

Zgodnie $z$ art. 3 projektu, zmiany proponowane w tych materiach (art. 1 pkt 2-7) weszłyby w życie $z$ dniem, w którym środkiem pieniężnym w Polsce stanie się wspólna waluta unijna - euro (wtedy też nastąpiłoby zniesienie Rady Polityki Pieniężnej i wygasłaby kadencja jej członków -art. 2 projektu).

Projekt prezydencki przewiduje - jak sygnalizowaliśmy - dodanie nowego, kompleksowego rozdziału Xa, regulującego członkostwo Polski w Unii Europejskiej. W sensie techniczno-legislacyjnym jest to tylko ,jedna” zmiana, ale zawierająca szereg zasadniczych przepisów. Zawarte tu przepisy w szczególności regulować mają takie materie jak: warunki członkostwa w UE (tzw. klauzula limitacyjna), tryb przekazywania kompetencji organów władzy państwowej w niektórych sprawach, status obywatela UE przebywającego na terytorium Polski, prawa wyborcze obywateli polskich oraz zamieszkałych na terytorium Polski obywateli UE niebędących obywatelami polskimi, relacje między Radą Ministrów, Sejmem i Senatem oraz Prezydentem w zakresie prowadzenia polityki Polski w UE, szczególne wymogi 
dotyczące projektów ustaw wykonujących prawo unijne, a także tryb wystąpienia Polski z Unii Europejskiej.

Przepisy nowego rozdziału Xa poniekąd uzupełnia, choć formalnie je poprzedza, propozycja $z$ art. 1 pkt 1 projektu, polegająca na uchyleniu dotychczasowego art. 90 konstytucji. Jak wcześniej sygnalizowaliśmy, reguluje on dotychczas przekazywanie organizacji międzynarodowej (lub organowi międzynarodowemu) kompetencji organów państwowych w niektórych sprawach, mając jednocześnie charakter uniwersalny. Przepis ten - jak dotychczas - został wykorzystany tylko dla przystąpienia Polski do Unii Europejskiej oraz dla ratyfikacji traktatu $z$ Lizbony, nie miał zaś w praktyce zastosowania w odniesieniu do organizacji międzynarodowych innych niż Unia Europejska. Zgodnie $z$ projektem prezydenckim podstawę przekazywania kompetencji na rzecz UE miałyby stanowić nowe przepisy $z$ art. 227b i art. $227 d$.

Przepis „otwierający” regulacje $z$ rozdziału Xa (art. 227a) stanowi, że Rzeczpospolita Polska jest członkiem Unii Europejskiej, która szanuje suwerenność i tożsamość narodową państw członkowskich, respektuje zasady pomocniczości, demokracji, państwa prawnego, poszanowania przyrodzonej i niezbywalnej godności człowieka, wolności i równości oraz zapewnia ochronę wolności i praw człowieka porównywalną z ochroną tych wolności i praw w konstytucji. Przepis ten określa aksjologiczne podstawy udziału Polski w procesach integracji europejskiej, legitymując go w tychże limitowanych przepisem granicach. Przepis wzmacnia w ten sposób ochronę tych dóbr na polu integracji europejskiej. Wymienione tu wartości są tożsame z wartościami zawartymi w art. 2 Traktatu o Unii Europejskiej, co ma zapobiegać kolizji między normami unijnymi i Konstytucji RP. Przepis adresowany jest do polskich organów władzy publicznej, eksponując granice konstytucyjne dla członkostwa Polski w UE. Innymi słowy, Polska- zgodnie z projektem - nie ma konstytucyjnego obowiązku uczestniczyć w UE, która nie respektowałaby wymienionych wartości, ani też nie ma konstytucyjnego obowiązku wykonywania prawa unijnego, które naruszałoby te wartości. Przepis stanowi wyraźną nowość normatywną na tle dotychczasowego art. 90 konstytucji, będąc przy tym jednoznaczną podstawą konstytucyjną dla członkostwa Polski w UE. 
Przepis art. 227b projektu stanowi, że Rzeczpospolita Polska może przekazać Unii Europejskiej kompetencje organów władzy państwowej w niektórych sprawach. Stanowi on podstawę przekazywania kompetencji na rzecz UE w przyszłości, a więc upoważnia do zawierania traktatów reformujących UE, w szczególności przekazujących jej dodatkowe kompetencje. Jest odpowiednikiem dotychczasowego art. 90 ust. 1 konstytucji.

Przepis art. 227c projektu jest najobszerniejszy, zawiera bowiem aż sześć ustępów i stanowi, że:

1. Ratyfikacja przez Rzeczpospolitą Polską umowy międzynarodowej stanowiącej podstawę przekazania kompetencji, o których mowa w art. 227 b, wymaga uprzedniej zgody wyrażonej w ustawie albo w referendum ogólnokrajowym.

2. Uchwałę w sprawie wyboru trybu wyrażenia zgody na ratyfikację umowy międzynarodowej, o której mowa w ust. 1, podejmuje Sejm bezwzględną większością głosów w obecności co najmniej połowy ustawowej liczby posłów.

3. Ustawę wyrażającą zgodę na ratyfikację umowy międzynarodowej, o której mowa w ust. 1, uchwala Sejm większością 2/3 głosów w obecności co najmniej połowy ustawowej liczy posłów oraz Senat bezwzględną większością głosów w obecności co najmniej połowy ustawowej liczby senatorów.

4. Zgoda na ratyfikację zostaje wyrażona, jeżeli w referendum ogólnokrajowym opowiedziała się za nią większość głosujących.

5. Ważność referendum ogólnokrajowego stwierdza Sąd Najwyższy.

6. Zasady i tryb przeprowadzania referendum określa ustawa.

Wymienione przepisy w zakresie art. 227c. ust. 1-4 stanowią odpowiednik dotychczasowego art. 90 ust. 2-4 Konstytucji, choć z merytorycznymi zmianami. Co jednak ważne, przepis art. 227c określa procedurę przekazywania kompetencji państwa na rzecz UE przy uwzględnieniu nowelizacji wprowadzonych traktatem $z$ Lizbony, dotycząc tylko przekazywania kompetencji na podstawie umowy międzynarodowej. Przepis ust. 3 odchodzi od dotychczas istniejącego w art. 90 ust. 2 in fine wymogu większości 2/3 głosów w Senacie (wprowadzając wymaganie większości bezwzględnej), co oznacza 
odejście od dotychczasowego warunku, bardziej rygorystycznego niż dla zmiany konstytucji. Przepis nowego ust. 4 znosi dotychczasowy wymóg frekwencji dla ważności referendum, który jest przewidziany w art. 90 ust. 3 przez odesłanie do art. 125 konstytucji; przyjęcie większości "głosujących” oznacza również odejście od wymogu surowszego niż w referendum konstytucyjnym $z$ art. 235 ust. 6 in fine konstytucji. Przepisy ust. 5-6 stanowią w zakresie konstytucjonalizacji materii nowość normatywną.

Przepis projektowanego nowego art. $227 \mathrm{~d}$ przewiduje w ust. 1, że przepisy art. 227c stosuje się odpowiednio w przypadku zmiany postanowień traktatów stanowiących podstawę Unii Europejskiej w sposób inny niż w drodze umowy międzynarodowej, o ile zmiana ta pociąga za sobą przekazanie kompetencji na rzecz Unii Europejskiej. Przy czym zasady postępowania określa ustawa, zaś w ust. 2 mówi, że zasady i tryb wyrażania przez Rzeczpospolitą Polską zgody na inną niż określona w ust. 1 zmianę postanowień traktatów stanowiących podstawę Unii Europejskiej oraz postępowanie w tych sprawach określa ustawa.

Przepisy art. 227d nawiązują do faktu, że traktaty stanowiące podstawę UE zawierają przepisy umożliwiające zmianę tych traktatów w uproszczonych procedurach (tzw. procedury „kładki”); rozróżnia się przy tym uproszone procedury zmiany z zastrzeżeniem ratyfikacji oraz bez takiego zastrzeżenia. Artykuł 227d projektu dotyczy „uproszczonych procedur zmiany” traktatów, przy czym na gruncie tego przepisu można wyróżnić dwa rodzaje zmian: takie, które pociągają za sobą przekazanie kompetencji, oraz które nie pociągają za sobą przekazania kompetencji. Zmiany oznaczające przekazanie kompetencji wymagają stosowania przepisów art. 227c, przy czym zasady postępowania określa ustawa. W pozostałych wypadkach procedurę wyrażania przez Polskę zgody na zmianę traktatów ma określić ustawa zwykła.

Przepis art. 227e projektu stanowi, że obywatel Unii Europejskiej korzysta na terytorium Rzeczypospolitej Polskiej z wolności i praw gwarantowanych w prawie Unii Europejskiej w zakresie jej kompetencji. Przepis ten dotyczy zarówno obywateli polskich, jak i innych obywateli UE. Potwierdza więc obywatelom polskim 
korzystanie z praw „unijnych”, gwarantowanych obywatelom UE. Jednocześnie rozstrzyga, że przepisy Konstytucji RP, gwarantujące określone prawa obywatelom polskim, wyznaczają jedynie minimalny zakres podmiotowy tych praw i nie stoją na przeszkodzie rozszerzeniu tego zakresu na obywateli innych państwa UE, gdy wymaga tego prawo unijne.

Przepis art. $227 \mathrm{f}$ projektu stanowi w ust. 1 , że obywatel polski oraz zamieszkały na terytorium Rzeczypospolitej Polskiej obywatel Unii Europejskiej niebędący obywatelem polskim mają prawo wybierania i prawo uczestnictwa w wyborach do Parlamentu Europejskiego na zasadach określonych w prawie Unii Europejskiej oraz w ustawie, zaś w ust. 2, że obywatel Unii Europejskiej niebędący obywatelem polskim zamieszkały na terytorium Rzeczypospolitej Polskiej ma prawo wybierania i prawo uczestnictwa w wyborach organów samorządu terytorialnego na zasadach określonych w prawie Unii Europejskiej oraz w ustawie.

Proponowany przepis w zakresie konstytucyjnym stanowi nowość normatywną i jest reakcją na fakt, że obowiązująca Konstytucja RP nie zawiera ani przepisów dotyczących wyborów do Parlamentu Europejskiego, ani dotyczących udziału obywateli innych państw w wyborach samorządowych. Propozycja w odniesieniu do obywateli UE dotyczy tylko wyborów samorządowych i tylko w zakresie, w jakim przewiduje to prawo unijne.

Przepis art. 227g projektu stanowi, że Rzeczpospolita Polska podejmuje działania niezbędne dla zapewnienia skuteczności prawa Unii Europejskiej w krajowym porządku prawnym. W proponowanym przepisie chodzi nie tylko o powstrzymanie się przez organy władzy publicznej od działań naruszających prawo unijne, ale także o podjęcie pozytywnych działań na rzecz wykonywania tego prawa. Zapewnienie prawidłowego i terminowego wykonywania prawa UE ma istotne znaczenie m.in. dla uniknięcia wysokich sankcji finansowych przewidzianych prawem unijnym. Traktat $z$ Lizbony upraszcza i przyspiesza bowiem procedurę wymierzania sankcji wobec państw członkowskich naruszających prawo UE. Proponowany przepis godzi przy tym w ochronę suwerenności państwa ze zobowiązaniami zaciągniętymi przez Polskę $\mathrm{w}$ związku $\mathrm{z}$ przystąpieniem do UE, 
przyjęta tu formuła nie rozstrzyga bowiem jednoznacznie o charakterze relacji między prawem UE a Konstytucją RP i pozostawia sporą elastyczność.

Przepisy art. 227h projektu obejmują cztery ustępy, które mówią, że:

1. Rada Ministrów prowadzi politykę Rzeczypospolitej Polskiej w Unii Europejskiej.

2. Sejmi Senat wykonują kompetencje powierzone parlamentom narodowym w traktatach stanowiących podstawę Unii Europejskiej w zakresach i formach określonych w tych traktatach.

3. Prezydent Rzeczypospolitej w zakresie polityki Rzeczypospolitej Polskiej w Unii Europejskiej współdziała z Prezesem Rady Ministrów i właściwym ministrem.

4. Organy władzy publicznej wykonują swoje kompetencje oraz współdziałają w sprawach Unii Europejskiej na zasadach określonych w ustawie.

Przepisy te normują kompetencje organów władzy publicznej w stosunkach z UE. Przepis ust. 1 określa organ dysponujący zasadniczą kompetencją, czyniąc nim Radę Ministrów. Rozwiązanie to jest spójne $z$ art. 146 Konstytucji RP, który stanowi, że Rada Ministrów prowadzi politykę wewnętrzną i zagraniczną RP. Proponowany ust. 2 potwierdza kompetencje Sejmu i Senatu przyznane traktatowo parlamentom narodowym, przy czym jest potrzebny m.in. dla wyraźnego dopuszczenia wyjątku od zasady wyrażonej w ust. 1 (właściwości Rady Ministrów). Na gruncie traktatu z Lizbony, przyznającego nowe kompetencje parlamentom narodowym, Sejm i Senat mają równorzędne kompetencje w określonych nim sprawach; zaproponowany ust. 2 wyraża wyjątek do ogólnych założeń Konstytucji RP w odniesieniu do dwuizbowości, w myśl których izby są nierównoprawne i Senat ma mniejsze kompetencje niż Sejm. Projektowany ust. 3 wzorowany jest na przepisie art. 126 ust. 3 konstytucji, przewidującym, że Prezydent RP w zakresie polityki zagranicznej współdziała $z$ Prezesem Rady Ministrów i właściwym ministrem; ze względu na wprowadzenie do konstytucji osobnego rozdziału, dotyczącego członkostwa Polski w UE, uznano za zasadne zawarcie w nim regulacji dotyczącej współdziałania organów 
w ramach dualistycznej egzekutywy w zakresie polityki unijnej RP. Zaproponowane tu brzmienie przepisu ma u podstaw także wspomniane już postanowienie Trybunału Konstytucyjnego z 20 maja 2009 roku (sygn. Kpt 2/08), rozstrzygające spór kompetencyjny między obu organami władzy wykonawczej na tle uprawnienia do reprezentowania RP na posiedzeniach Rady Europejskiej w celu reprezentowania stanowiska kraju. Postanowienie to wyeksponowano obowiązek współdziałania organów. Proponowany ust. 4 zawiera zaś unormowanie dwojakie: po pierwsze - przepis wyraża ogólną zasadę konstytucyjną współdziałania organów władzy publicznej (w zakresie nieobjętym regulacją z ust. 3) w sprawach unijnych, przy czym pojęcie organów władzy publicznej obejmuje zarówno organy naczelne, jak i lokalne, które biorą udział w procedurach współdziałania w sprawach unijnych zależnie od konkretnej sytuacji i przyznanych im kompetencji oraz - po drugie - przepis nakazuje ustawodawcy określenie w ustawie wspomnianych zasad współdziałania.

Przepisy art. 227i stanowią w ust. 1, że Rada Ministrów wnosi do Sejmu projekt ustawy wykonującej prawo Unii Europejskiej w terminie umożliwiającym jej wejście w życie odpowiednio do wymogów określonych w prawie Unii Europejskiej, przy czym szczegółowe terminy określa ustawa, zaś w ust. 2 mówi, że do projektu ustawy wykonującej prawo Unii Europejskiej uznanej przez Radę Ministrów za pilny nie stosuje się ograniczeń, o których mowa w art. 123 ust. 1 Konstytucji RP. Oba zaproponowane rozwiązania konstytucjonalizacja rządowego obowiązku temporalnego w zaproponowanym kształcie (ust. 1) i rozszerzenie zakresu stosowania trybu pilnego stanowienia ustaw (ust. 2) - służyć mają szybszej (a zwłaszcza terminowej) implementacji przepisów unijnych przez polskiego ustawodawcę. Jak wcześniej wspominaliśmy, opóźnienia narażają państwo na dotkliwe sankcje finansowe oraz odszkodowania $z$ tytułu naruszenia prawa unijnego. Zniesienie dotychczasowych ograniczeń konstytucyjnych stosowania trybu pilnego dotyczy ich zakresu przedmiotowego, co oznacza, że tryb pilny będzie mógł być stosowany we wszelkich sprawach należących do zakresu kompetencji UE; w szczególności może to mieć znaczenie dla implementacji przepisów z zakresu prawa podatkowego. 
Przepis art. 227j projektu stanowi, że postępowanie w sprawie ustawy wykonującej prawo Unii Europejskiej niezakończone przed upływem kadencji Sejmu podlega kontynuacji w następnej kadencji na zasadach określonych w ustawie. Również i ten przepis służyć ma terminowej implementacji prawa unijnego, eliminując obowiązującą w polskim prawie zasadę „dyskontynuacji” prac, oznaczającą, że postępowania ustawodawcze ulegają zamknięciu z końcem kadencji, a Sejm następnej kadencji nie rozpatruje projektów ustaw wniesionych w poprzedniej kadencji. Użyte w zaproponowanym przepisie pojęcie „postępowania w sprawie ustawy” obejmuje wszelkie etapy postępowania - od inicjatywy ustawodawczej po podpis Prezydenta pod ustawą - co oznacza, że prace nad ustawą implementacyjną będą w kolejnej kadencji kontynuowane bez względu na to, do którego punktu doszło postępowanie w sprawie ustawy w chwili zakończenia poprzedniej kadencji Sejmu.

Ostatni przepis nowego rozdziału (art. 227k) stanowi w ust. 1, że Rada Ministrów podejmuje decyzję o wystąpieniu Rzeczypospolitej Polskiej z Unii Europejskiej za zgodą wyrażoną w trybie, o którym mowa w art. 227c, zaś w ust. 2 - że ratyfikacja umowy międzynarodowej określającej warunki wystąpienia Rzeczypospolitej Polskiej z Unii Europejskiej wymaga zgody wyrażonej w trybie, o którym mowa w art. 227c, a w ust. 3 jest mowa o tym, że zasady postępowania w sprawie wystąpienia Rzeczypospolitej Polskiej z Unii Europejskiej określa ustawa.

Przepisy art. 227k regulują wystąpienie Polskiej z UE zgodnie $z$ postanowieniami traktatów stanowiących podstawę UE. Traktat z Lizbony wyraźnie przyznaje państwom członkowskim prawo wystąpienia z UE i normuje szczegółowo postępowanie w tej sprawie. W myśl traktatów wystąpienie obejmuje trzy etapy: podjęcie przez państwo członkowskie decyzji w sprawie wystąpienia z UE, notyfikację przez państwo członkowskie zamiaru wystąpienia oraz zawarcie umowy międzynarodowej określającej warunki wystąpienia danego państwa z UE. W myśl proponowanego przepisu, decyzja o wystąpieniu RP z UE wymaga zgody wyrażonej w trybie analogicznym jak przy przekazywaniu kompetencji na rzecz UE; po uzyskaniu takiej zgody Rada Ministrów może notyfikować zamiar wystąpienia Polski 
z UE. Ratyfikacja umowy międzynarodowej określającej warunki wystąpienia także wymaga zgody wyrażonej w trybie podobnym do przekazywania kompetencji na rzecz UE - co jest uzasadnione faktem, że może ona mieć bardzo daleko idące konsekwencje finansowe, gospodarcze i społeczne. Zasady postępowania w sprawie wystąpienia RP z UE ma określić ustawa.

\section{STRESZCZENIE}

Uregulowania konstytucji krajowej w perspektywie integracji europejskiej oraz kierunki niezbędnych uzupełnień

Problem „wymiaru unijnego” Konstytucji RP szybko stał się przedmiotem szerokich analiz doktrynalnych, prowadząc rychło do daleko idącego konsensusu co do potrzeby, granic i meritum pożądanych uzupełnień i zmian $\mathrm{w}$ treści obowiązującej ustawy zasadniczej, w tym również wskazania, $\dot{z}$ - - w zasadzie - materia ta winna stanowić przedmiot uregulowania kompleksowego w nowym rozdziale konstytucji. Swoistym „ukoronowaniem” tego nurtu jest zapewne projekt ustawy o zmianie konstytucji (wraz z uzasadnieniem) z 30 czerwca 2010 roku, stanowiący bezpośrednio rezultat prac zespołu naukowego, powołanego przez Marszałka. W drugiej połowie VI kadencji zostały wniesione do Sejmu cztery projekty ustaw o zmianie konstytucji. Trzy z nich dotyczyły - po raz pierwszy w 12 roku obowiązywania konstytucji - „materii unijnej”. Żaden $z$ tych projektów nie został jednak uchwalony i z końcem kadencji Sejmu zostały one objęte zasadą dyskontynuacji. Stanowią one jednak oficjalny obraz wyobrażeń i dążeń sił politycznych co do konstytucyjnej regulacji interesującej nas materii. Najistotniejsze znaczenie odgrywał w nim projekt prezydencki z 12 listopada 2010 roku dotyczący kwestii wynikających z przynależności Polski do Unii Europejskiej i jemu też najwięcej uwagi.

Słowa klucze: Konstytucja RP, euronowelizacja, konstytucyjne podstawy członkostwa Polski w Unii Europejskiej, projekt ustawy o zmianie konstytucji. 


\section{SUMMARY}

The perspectives of the membership of the Republic of Poland in the European Union in the light of "Euro-Amendment"

Proposed in Bills Amending the Constitution

Following several years of Poland's membership of the EU and after the ratification and entryinto force of the Lisbon Treaty, the idea of a largescale "Euro-Amendment" has reached its "constitutional moment". In this article the author makes an attempt to analyse a Presidential Bill which was mostly the result of work of the science team established in 2009 by Bronisław Komorowski, the then Marshal of the Sejm (Sejm Paper No. 3598), which providing for a wide-ranging review of the constitution in connection with Poland's membership of the EU.

Keywords: the membership of the Republic of Poland in the European Union, "Euro-Amendment" Proposed in Bills Amending the Constitution.

\section{BIBLIOGRAFIA}

Galster J., Konstytucja Rzeczypospolitej Polskiej wobec postępów integracji europejskiej. Diagnoza stanu europeizacji ustawy zasadniczej, w: Dziesięć lat Konstytucji Rzeczypospolitej Polskiej, red. E. Gdulewicz, H. Zięba-Załucka, Rzeszów 2007.

Kustra A., „Euronowelizacja” w projektach o zmianie ustaw Konstytucji RP. Próba oceny, „Przegląd Sejmowy” 2011, nr 3.

Szmyt A., Aktualne problemy rozwoju prawa konstytucyjnego $w$ Polsce ( $w$ świetle projektu ustawy o zmianie konstytucji z 19 lutego 2010 r.), w: Ustavni system Ceske Republiky a Polske Republiky po pristoupeni $k$ Europske Unii, red. V. Jiraskova, Z. Witkowski, Praga 2011.

Szmyt A., O dwóch przykładach wątpliwości $w$ sprawie zamierzeń legislacyjnych, w: Państwo i prawo wobec wspótczesnych wyzwań, t. 3: Zagadnienia prawa konstytucyjnego. Księga jubileuszowa Profesora Jerzego Jaskierni, red. R. M. Czarny, K. Spryszak, Torun 2012.

Zmiany w Konstytucji RP dotyczące członkostwa Polski w Unii Europejskiej. Dokumenty z prac zespołu naukowego powołanego przez Marszałka Sejmu, Warszawa 2010. 